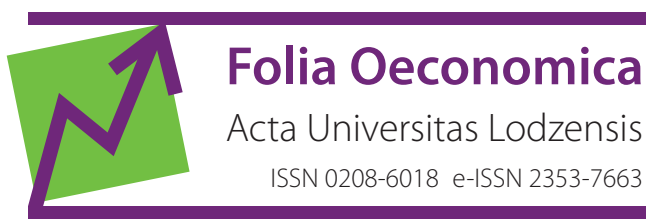

www.czasopisma.uni.lodz.pl/foe/

$1(327) 2017$

DOI: http://dx.doi.org/10.18778/0208-6018.327.11

\title{
Radosław Piwowarski
}

Uniwersytet Łódzki, Wydział Ekonomiczno-Socjologiczny, Instytut Ekonomii,

Katedra Funkcjonowania Gospodarki, radpiw@uni.lodz.pl

\section{Czy wskaźnik efektywności zatrudnieniowej ulega paradoksowi efektywności?}

Streszczenie: W opublikowanym w 2015 roku raporcie Najwyższej Izby Kontroli (NIK) na temat skuteczności wybranych form aktywnego przeciwdziałania bezrobociu znajdują się wnioski wskazujące na możliwość występowania paradoksu efektywności. Dotyczy to przede wszystkim stosowanego przez powiatowe urzędy pracy wskaźnika efektywności zatrudnieniowej (WEZ). Celem artykułu jest charakterystyka zjawiska paradoksu efektywności oraz ocena możliwości jego występowania w przypadku WEZ. Realizując cel, analizuje się dane statystyczne publikowane przez MPiPS i GUS, odnoszące się do funkcjonowania aktywnych form przeciwdziałania bezrobociu w okresie od 2009 do 2014 roku na poziomie województw. Bada się również korelacje wskaźnika efektywności zatrudnieniowej ze stopami odpływu z bezrobocia z tytułu podjęcia pracy i zatrudnienia po aktywizacji. Z przeprowadzonej analizy wynika, że przedstawiony w raportach MPiPS obraz działalności powiatowych urzędów pracy jest bardziej optymistyczny od rzeczywistego. Jest to zjawisko charakterystyczne dla występowania paradoksu efektywności, któremu WEZ wydaje się ulegać.

Słowa kluczowe: paradoks efektywności, wskaźnik efektywności zatrudnieniowej, rynek pracy, efektywność sektora publicznego

JEL: $\mathrm{H} 4, \mathrm{~J} 08$ 


\section{Wprowadzenie}

Wraz z pojawieniem się na przełomie lat siedemdziesiątych i osiemdziesiątych XX wieku paradygmatu Nowego Zarządzania Publicznego (NZP) (ang. New Public Manage$m e n t)$, położono duży nacisk na efektywność funkcjonowania sektora publicznego. Odzwierciedleniem tego było wprowadzanie narzędzi i sposobów charakterystycznych dla funkcjonowania sektora prywatnego. Można tu wymienić choćby: bazowanie na wskaźnikach efektywności w ocenach wewnętrznych i zewnętrznych, zwiększanie roli oraz odpowiedzialności menedżerów, traktowanie petentów jak klientów, których opinie kształtują sposób działalności sektora etc. (Osoborne, 2006: 378-379; Christensen, Laegreid, 2015: 207-208). Tworzenie w ten sposób konkurencyjnego środowiska miało przynieść wiele korzyści w działalności administracji publicznej (Utz, 2011: 1). Powinny się one pojawić automatycznie, gdyż to, co rynkowe, w większości przypadków uznaje się za efektywne.

Rynkowe, menedżerskie podejście (ang. managerialism) skutkowało szeregiem reform funkcjonowania sektora publicznego, których wzorcami stały się takie państwa, jak Nowa Zelandia, Australia czy Wielka Brytania (van Dooren, Bouckaert, Halligan, 2015: 48-49; Piwowarski, 2011: 93). Ich sukcesy w efektywnym zarządzaniu sektorem, zmniejszającym koszty jego funkcjonowania, utwierdzały o słuszności podjętych reform ${ }^{1}$. Pomimo wielu sukcesów i pozytywów rynkowego podejścia do zarządzania sektorem publicznym w literaturze wskazuje się na niebezpieczeństwa jego stosowania. Przede wszystkim odnosi się to do przyjmowanych narzędzi (mierników efektywności), które mogą prowadzić do paradoksu efektywności (ang. performance paradox).

W opublikowanym w 2015 roku raporcie Najwyższej Izby Kontroli (NIK) na temat skuteczności wybranych form aktywnego przeciwdziałania bezrobociu znajdują się wnioski wskazujące na możliwość występowania paradoksu efektywności ${ }^{2}$. Miałby jemu ulegać stosowany przez urzędy wskaźnik efektywności zatrudnieniowej. Przykładowo: w ogólnej ocenie kontrolowanej przez NIK działalności powiatowych urzędów pracy stwierdza się: „Z ustaleń kontroli wynika, że mimo wykazywania wysokich wskaźników efektywności zatrudnieniowej, efektywność ta - rozumiana jako trwałość zatrudnienia - była niska. Funkcjonujący system aktywizacji zachęcał z jednej strony do organizowania przez urzędy dużej liczby form, zaś z drugiej strony pozwalał łatwo wykazać w sprawozdawczości wysoką ich efektywność" (NIK, 2015: 8). Wnioski z raportu skłaniają do analizy

${ }^{1} \mathrm{~W}$ ujęciu globalnym miało to odzwierciedlenie np. w likwidacji deficytów budżetowych, a co za tym idzie - w zmniejszaniu udziału długu publicznego w PKB. Wpływało to na zmniejszenie wydatków i kosztów funkcjonowania sektora (Piwowarski, 2011: 95).

${ }^{2}$ Kontrola została przeprowadzona między 1 stycznia 2011 roku a 31 marca 2014 roku. Niektóre kontrolowane programy rozpoczynały się jednak już w 2009 roku. W prowadzonej analizie przyjmuje się analogiczny okres, tj. od 2009 do 2014 roku. 
funkcjonowania powiatowych urzędów pracy z punktu widzenia „efektywności” prowadzonych działań.

Celem artykułu jest charakterystyka zjawiska paradoksu efektywności oraz ocena możliwości jego występowania w przypadku wskaźnika efektywności zatrudnieniowej stosowanego przez powiatowe urzędy pracy (PUP-y) w Polsce. Realizując cel, analizuje się dane statystyczne publikowane przez MPiPS i GUS, odnoszące się do funkcjonowania aktywnych form przeciwdziałania bezrobociu w okresie od 2009 do 2014 roku na poziomie województw. Bada się również korelacje wskaźnika efektywności zatrudnieniowej ze stopami odpływu z bezrobocia $\mathrm{z}$ tytułu podjęcia pracy i zatrudnienia po aktywizacji.

\section{Paradoks efektywności}

Sektor publiczny posługuje się różnego rodzaju miernikami (wskaźnikami) ${ }^{3}$, które mają pokazywać efektywność działania całej organizacji i poszczególnych osób. Powszechność ich stosowania stanowi pochodną dość szerokiego wdrażania zasad NZP w zarządzaniu sektorem oraz rozwoju społeczeństw obywatelskich. Jak podkreśla P. Smith, stosowanie różnego rodzaju wskaźników w sektorze publicznym w Wielkiej Brytanii „eksplodowało” w latach osiemdziesiątych XX wieku, stając się powszechne. Nie bez znaczenia pozostaje również czynnik odpowiedzialności (ang. accountability), który „wymusza” na rządzących ujawnianie szeregu informacji, aby pokazać społeczeństwu efekty działalności sektora publicznego (Smith, 1990: 53-54). W założeniu przyjmuje się, że występuje korelacja między efektywnym działaniem a stosownym (zastosowanym) wskaźnikiem. Brak lub słaba zależność skutkuje paradoksem.

Paradoks efektywności (ang. performance paradox) odnosi się do słabej korelacji między wskaźnikiem efektywności a samą efektywnością (Meyer, Gupta, 1994: 309-369; Meyer, O’Shaughnessy, 1993: 249-278). Pod wpływem czasu wskaźnik ma tendencje do utraty zdolności mierzenia efektywności ${ }^{4}$, przez co na jego podstawie nie można odróżnić efektywnych i nieefektywnych działań (zachowań). W rezultacie zmniejsza się zależność między rzeczywistymi a raportowanymi działaniami, skutkując najczęściej zbyt optymistyczną oceną rzeczywistości (van Thiel, Leeuw, 2002: 271). Paradoks nie odnosi się zatem do samej działalności, a do efektów jej pomiaru (wskaźnik nie pokazuje właściwej oceny rzeczywistości).

Brak możliwości właściwego (odpowiedniego) pomiaru działań przez wskaźnik często pojawia się w sposób niezamierzony, będący rezultatem szeregu czynni-

\footnotetext{
${ }^{3}$ Słowa „miernik” i „wskaźnik” będzie stosować się zamiennie.

${ }^{4}$ Utrata zdolności pomiaru efektywności przez wskaźnik wynika z omawianych w dalszej części artykułu procesów.
} 
ków5 . Naturalne i racjonalne jest, że podmioty czy organizacje podlegające pomiarowi dostosowują swoje działania do środowiska, w jakim funkcjonują. Chcąc być jak najlepiej ocenionymi, będą dążyć do spełnienia narzuconych przez wskaźnik kryteriów. Według M.W. Meyera i V. Gupty pojawiają się wtedy cztery procesy, które powodują pogorszenie się zdolności pomiaru efektywności przez wskaźnik (Meyer, Gupta, 1994: 330-342):

1) pozytywne uczenie się (ang. positive learning) - polega na utracie wrażliwości do wykrywania złych zachowań przez wskaźnik w wyniku poprawy działalności przez podmioty podlegające ocenie; każdy z podmiotów staje się coraz lepszy;

2) odwrotne (przewrotne) uczenie się (ang. perverse learning) - polega na uczeniu się i skupianiu przez podmioty wyłącznie na aspektach podlegających pomiarowi; pozostałe wielkości są nieistotne, a przez to pomijane przy prowadzonej działalności; P. Smith określa ten proces jako wąskie patrzenie (ang. tunnel vision); przykładowo: w ramach stosowanego systemu mierników koncentruje się na zjawiskach mierzalnych kosztem niemierzalnych; podobnymi procesami są również suboptymalizacja, polegająca na wyborze przez menedżerów celów służących ich pozytywnemu odbiorowi, a nie całej organizacji, czy faworyzowanie mierzalnych celów (ang. measure fixation); w tym przypadku kładzie się nacisk na jeden pomiar sukcesu, a nie na leżące u jego podstaw cele oraz skupia się na łatwo mierzalnych wskaźnikach (Smith, 1995: 284-290; Leeuw, 2008: 5);

3) selekcja - sprowadza się do zastępowania złych podmiotów przez dobre, w rezultacie wszyscy stają się dobrzy i przestają występować różnice w wartości wskaźnika;

4) zahamowanie (ang. suppression) - polega na ignorowaniu różnic w wielkościach wskaźnika; proces ten koresponduje $\mathrm{z}$ procesem kostnienia (ang. ossification) wskazywanym przez P. Smitha; nie rewiduje się ani nie usuwa wskaźnika, który nie wypełnia już swojego celu; mimo to zaleca się jego stosowanie ${ }^{6}$.

Poza wymienionymi wyżej procesami P. Smith wskazuje jeszcze na kilka dodatkowych, które będą skutkować paradoksem efektywności (Smith, 1995: 284290). Będą to:

1) krótkowzroczność (ang. myopia), polegająca na skupianiu się bardziej na krótkookresowych niż na długookresowych celach;

${ }^{5}$ Można tu wymienić np. błędne założenia przyjęte przy budowie wskaźnika, błędną liczbę stosowanych wskaźników etc.

${ }^{6}$ Taka sytuacja ma miejsce, np. gdy menedżerowie dbają o to, aby sprostać wymaganiom mocodawcy odnośnie wartości wskaźników, ignorując przy tym działanie organizacji. Nie jest ważne, czy organizacja działa efektywnie tak długo, jak wskaźnik (wskaźniki) wskazują, że tak jest (van Thiel, Leeuw, 2002: 273). 
2) fałszywy obraz (ang. misrepresentation), który jest formą oszustwa polegającego na błędnym raportowaniu czy zakłócaniu wskaźnika w celu wywarcia dobrego wrażania';

3) błędna interpretacja (ang. misinterpretation), polegająca na prezentowaniu nieprecyzyjnych danych statystycznych;

4) hazard (ang. gaming), będący celową grą menedżerów, polegającą na sterowaniu wielkością wskaźnika między okresami rozliczeniowymi, np. aby „zabezpieczyć” niższe wielkości w kolejnym okresie; ze względu na celowość takiego działania może ono wybiegać poza niezamierzone procesy; możliwe jest jednak, że powyższe zachowanie nie wynika wyłącznie ze złej woli menedżera; dostosowuje on swoje zachowania do środowiska, w jakim musi funkcjonować; wydaje się, że za hazard można też uznać zjawisko „spijania śmietanki” (ang. cream skimming, cherry picking), będące tendencją do zachowań polegających na dostarczaniu usług tylko tym, którzy mogą być pokazani „we wskaźniku jako sukces” (lub na ich nadreprezentatywności w ogólnej liczbie usługobiorców); przykładowo: w urzędach pracy nie obsługuje się długotrwale bezrobotnych, a w służbie zdrowia pomija się chronicznie chorych pacjentów (van Thiel, Leeuw, 2002: 274).

Raportowane wskaźniki (wyniki) najczęściej pozostają głównym źródłem informacji na temat funkcjonowania organizacji sektora publicznego. Może się zdarzyć, że zewnętrzny odbiór w rzeczywistości źle funkcjonującej organizacji będzie pozytywny. Możliwe jest również zaistnienie odwrotnej sytuacji, gdy dobrze funkcjonująca organizacja publiczna prezentuje słabe wskaźniki efektywności. Z tego względu oceniając wskaźniki efektywności, powinno się przyjrzeć ich konstrukcji oraz motywacjom, jakie towarzyszyły ich wdrożeniu i stosowaniu. Warto również zestawiać ze sobą wskaźniki, aby uzyskać jak najszerszy obraz. Nie bez znaczenia pozostają także wzorce, dzięki którym możliwa jest ocena jakości wskaźnika.

\section{Cechy dobrego wskaźnika}

Według E.D. Rosen każda miara jest wielkością arbitralną. Nawet najbardziej naukowe jednostki pomiaru są wynikiem subiektywnych decyzji (Rosen, 1993: 71). Pomiar zmiennej jakościowej, za jaką często uznaje się efektywność, wiąże się z przyjęciem arbitralnych rozwiązań. Najczęściej podmioty sektora publicznego same formułują wskaźniki, na podstawie których podlegają ocenie. Nie należy tego faktu interpretować negatywnie, gdyż sam podmiot najlepiej zna specyfikę własnej działalności i powinien dbać o jej jakość. Jak twierdzi H. de Bruijn, główną, a zarazem prostą ideą stojącą za mierzeniem efektywności jest formułowanie przez profesjonalną organizację zakładanego celu i wskazanie, jak będzie mierzo-

\footnotetext{
${ }^{7}$ Wydaje się, że można utożsamiać takie działanie z kreatywną księgowością.
} 
ny, następnie pokazanie, czy cel został osiągnięty oraz jakie poniesiono w związku z tym koszty (de Bruijn, 2007: 7). Takie postępowanie umożliwia zewnętrznym podmiotom ocenę przyjętego rozwiązania.

Sektor publiczny od przeszło pół wieku promuje stosowanie wskaźników efektywności (Grizzle, 2002: 363). Mają one na celu: zwiększać przejrzystość działalności sektora (przez co prowadzić do bardziej odpowiedzialnych zachowań), sprzyjać uczeniu się przez korygowanie złych czy poprawę dobrych zachowań, przekazywać informacje (powiadamiać) o prowadzonej działalności oraz oceniać (sankcjonować) zarówno złe, jak i dobre zachowania (de Bruijn, 2007: 7).

Powszechność używania wskaźników będzie skutkować jakościowymi różnicami między nimi. Problemem do rozwiązania jest odróżnienie dobrego wskaźnika od złego. Chcąc rozstrzygnąć elementarne wątpliwości, można odwołać się do prostej idei leżącej u podstaw efektywności. Zgodnie z nią na początku formułuje się cel, a następnie pokazuje sposób jego osiągnięcia oraz metodę pomiaru. Pierwszą weryfikacją powinna być zatem konfrontacja zgodności miernika z przyjmowanym przez organizację celem ${ }^{8}$. Kolejne oceny odnoszą się już do samego wskaźnika. Według E.D. Rosen można wskazać wiele cech, jakim powinien charakteryzować się dobry wskaźnik, mimo to kilka z nich można uznać za najbardziej istotne (Rosen, 1993: 74-75). Będą to:

1) słuszność i wiarygodność (ang. validity and reliability) - słuszność miernika odnosi się do właściwego sposobu pomiaru tego, co chce się mierzyć; przykładowo: chcąc mierzyć szybkość dostarczenia przesyłki, należy dokładnie sprecyzować odcinek, na jakim ma nastąpić pomiar, tj. od jakiego podmiotu do jakiego, uwzględniając czynniki zewnętrzne, niezależne od podmiotów, a mogące zakłócić ten proces; wiarygodność dotyczy niezmienności w czasie wskaźnika oraz jego jednoznacznej interpretacji;

2) jasność (ang. clarity) - miernik powinien być zrozumiały, co implikuje, że nie powinien być zbyt skomplikowany;

3) istotność i możliwość kontroli (ang. relevancy and controllability) - istotność odnosi się do zapewnienia informacji niezbędnych do podejmowania decyzji; właściwa kontrola polega natomiast na wszechstronnym uwzględnieniu ważnych czynników; należy pomijać takie, które nie podlegają zmianom czy mają niewielki wpływ na mierzoną wielkość;

4) precyzja i elastyczność (ang. accuracy and sensitivity) - precyzyjna miara nie powinna mieć „wbudowanych” skłonności do zakłóceń czy tendencyjności pomiaru; elastyczność miernika będzie polegać na uwzględnianiu pośrednich wielkości; przykładowo: droga nie powinna być oceniana, czy jest wyłącznie czysta, czy brudna - potrzeba również ocen pośrednich;

${ }^{8}$ Jeżeli przyjęty miernik nie jest w stanie zmierzyć lub w niewielki sposób mierzy realizowany cel, powinien być odrzucony i zastąpiony innym. 
5) praktyczność (ang. practicality) - stosowanie miernika powinno uwzględniać koszty gromadzenia danych czy łatwość ich uzyskania; nie powinno to jednak stanowić przeszkody w stosowaniu dobrego miernika, który wart jest wysiłku w uzyskaniu danych.

Analizując powyższą listę cech, można zauważyć, że niektóre z jej elementów przeczą sobie. Przykładowo: chcąc zapewnić jasność miernika (czyli jego prostotę), można nie uzyskać kontroli wszystkich istotnych czynników. W takim wypadku ponownie warto odnieść się do celu stosowania miernika i uzasadnić, dlaczego skupia się na danych jego cechach. Należy też pamiętać, że w przypadku zrealizowania zakładanego przez organizację celu, zasadność stosowania miernika powinna być ponownie zweryfikowana.

\section{Wskaźnik efektywności zatrudnieniowej (WEZ) a paradoks efektywności}

Powiatowe urzędy pracy (PUP-y) w Polsce podlegają ocenie efektywności prowadzonych działań. Generalnym celem stawianym przed nimi jest walka $\mathrm{z}$ bezrobociem. Realizowane programy aktywizacji zawodowej mają służyć wyjściu z bezrobocia. Skuteczność ich realizacji mierzy $W E Z$.

Według MPiPS efektywność zatrudnieniową (tj. wskaźnik ponownego zatrudnienia) definiuje się jako stosunek liczby osób bezrobotnych, które po zakończeniu udziału w danym roku (np. 2014) w określonej formie aktywizacji uzyskały w okresie do 3 miesięcy zatrudnienie, tj. wyrejestrowały się z PUP lub jeżeli w okresie do 3 miesięcy od czasu zakończenia udziału w programach nie zarejestrowały się w PUP, do liczby osób, które danym roku (w tym przypadku 2014) zakończyły udział w danej formie aktywizacji (MPiPS, 2015: 5).

Zgodnie z powyższą definicją wzrost efektywności zatrudnieniowej oznacza, że działania urzędów pracy zwiększają odpływy z zasobu bezrobocia, przez co pozytywnie oddziałują na stopę bezrobocia. Jej zmniejszenie jest korzystne dla gospodarki. Występuje teoretyczna zgodność między zwiększaniem efektywności działań urzędów a poprawą sytuacji w gospodarce. Powinno się zatem nagradzać i promować najlepiej działające w tym obszarze urzędy. Z tego punktu widzenia zaproponowane w Ustawie z dnia 20 kwietnia 2005 r. o promocji zatrudnienia i instytucjach rynku pracy rozwiązania wydają się zasadne. W ich świetle otrzymanie dodatkowych środków na nagrody dla pracowników PUP uzależnione jest od osiąganej efektywności zatrudnieniowej’. Chęć wykazywania się wysoki-

${ }^{9}$ Przepisy dotyczące wielkości przekazywanej kwoty oraz warunków, jakie należy spełnić, zawarte są w art. 108 ust. 1 i oraz art. 109 ust. 7h-7j ustawy. Warunek odnoszący się do efektywności zatrudnieniowej mówi, że w roku poprzedzającym rok złożenia wniosku $W E Z$ podstawo- 
mi wskaźnikami wydaje się zatem dość naturalna. Kierownictwu powiatowych urzędów pracy będzie zależeć, aby uzyskiwany wskaźnik był jak najwyższy.

Od 2009 roku obserwuje się wzrost wartości WEZ obliczonego jako średnia dla wszystkich urzędów pracy (por. wykres 1), przy czym od 2011 roku odnotowuje się znaczne zwiększenie dynamiki wzrostu WEZ. Najbardziej znaczącą zmianę, niecałe 13 p.p., odnotowano w roku $2014^{10}$. W pozostałych okresach wzrosty wahały się w przedziale od 1 do 5,2 p.p. W latach 2009-2011 obserwowano zmiany wynoszące około 1 p.p. W okresie 2009-2014 zmniejszyła się różnica między „najlepszym” a „najgorszym” urzędem z 24,9 p.p. w 2009 roku do 12,7 p.p. w 2014 roku. Wydaje się, urzędy ,upodabniają się do siebie” w swoich działaniach dotyczących poprawy WEZ. Potwierdza to mediana, która jest bardzo zbliżona do średniej, a w latach 2012 i 2014 nawet ją przewyższała. Oznacza to, że więcej urzędów jest lepszych niż gorszych. Przykładowo: w 2014 roku na 340 urzędów 292 poprawiło efektywność zatrudnieniową $(85,9 \%)^{11}$. Może to wskazywać na proces pozytywnego uczenia się.

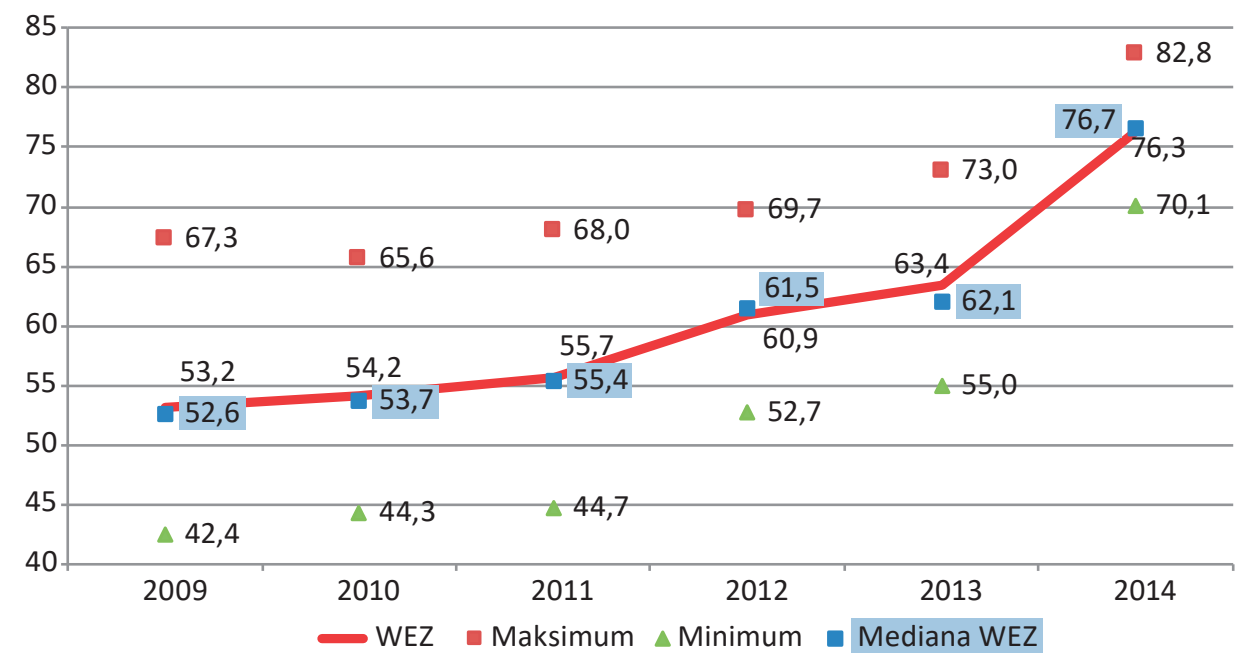

Wykres 1. Wskaźnik efektywności zatrudnieniowej w latach 2009-2014 (w \%)

Źródło: opracowanie własne na postawie danych MPiPS

wych form aktywizacji zawodowej ma być na poziomie wyższym niż 2 punkty procentowe poniżej średniej efektywności zatrudnieniowej podstawowych form aktywizacji zawodowej uzyskanej we wszystkich powiatowych urzędach pracy.

${ }^{10}$ Ministerstwo tłumaczy ten wzrost ,znaczącym wzrostem udziału środków na utworzenie stanowiska pracy, których efektywność zatrudnieniowa wynosi 100\% oraz faktem, że w 2014 r. analiza efektywności nie obejmowała prac społecznie użytecznych (PSU), których efektywność (cząstkowa) znacząco obniżała efektywność ogólną wszystkich form” (MPiPS, 2015: 10).

${ }^{11}$ Warto w tym miejscu dodać, że efektywność kosztową poprawiły jednie 183 urzędy (MPiPS, 2015: 12,17). 
Obserwowane w ostatnich latach dynamiczne zmiany wartości wskaźnika skłaniają do refleksji nad jego zdolnością mierzenia efektywnych działań przez PUP-y. W tym celu analizuje się wewnętrzną strukturę wskaźnika ${ }^{12}$ oraz liczbę uczestników form aktywizacji w latach 2009-2014 (por. tab. 1 i 2).

Tabela 1. Wskaźnik efektywności zatrudnieniowej według form aktywizacji w latach 2009-2014 (w \%)

\begin{tabular}{|l|r|r|r|r|r|r|}
\hline \multicolumn{1}{|c|}{ Forma aktywizacji zawodowej/lata } & $\mathbf{2 0 0 9}$ & $\mathbf{2 0 1 0}$ & $\mathbf{2 0 1 1}$ & $\mathbf{2 0 1 2}$ & $\mathbf{2 0 1 3}$ & $\mathbf{2 0 1 4}$ \\
\hline Szkolenia & 34,3 & 36,7 & 43,1 & 42,5 & 47,6 & 55,6 \\
\hline Prace interwencyjne & 71,8 & 70,8 & 71,4 & 74,4 & 77,5 & 74,1 \\
\hline Roboty publiczne & 48,0 & 46,0 & 53,2 & 57,3 & 60,0 & 72,3 \\
\hline Prace społecznie użyteczne* & 39,8 & 39,8 & 36,1 & 33,0 & 19,0 & - \\
\hline Przygotowanie zawodowe w miejscu pracy** & 52,0 & - & - & - & - & - \\
\hline Staże & 49,5 & 48,4 & 52,6 & 60,9 & 65,8 & 74,1 \\
\hline Środki na utworzenie stanowisk pracy, w tym: & 100,0 & 100,0 & 100,0 & 100,0 & 100,0 & 100,0 \\
\hline Podjęcie działalności gospodarczej & 100,0 & 100,0 & 100,0 & 100,0 & 100,0 & 100,0 \\
\hline Wyposażenie i doposażenie miejsca pracy & 100,0 & 100,0 & 100,0 & 100,0 & 100,0 & 100,0 \\
\hline
\end{tabular}

* Uwzględniane we wskaźniku do 2013 r.

** Uwzględniane we wskaźniku do 2009 r.

\section{Źródło: opracowanie własne na podstawie danych MPiPS, 2010-2015}

Jedyną formą aktywizacji zawodowej, która na przestrzeni lat 2009-2013 obniżała swoją efektywność, były prace społecznie użyteczne. W sprawozdaniu MPiPS brak jest szczegółowego uzasadnienia usunięcia tej formy ze wskaźnika (MPiPS, 2015: 10). Jego wynikiem jest natomiast znaczny wzrost efektywności zatrudnieniowej raportowanej przez urzędy. W przypadku pozostałych form aktywizacji ich efektywność podlegała wahaniom.

W okresie 2013-2014 odnotowano spadek efektywności zatrudnieniowej tylko dla prac interwencyjnych (o 4,39\%). W tym samym okresie dla szkoleń, robót publicznych i staży obserwowano wzrosty wskaźników, odpowiednio: $16,81 \%$, $20,5 \%$ i $12,61 \%$.

Ze względu na stosowaną przez PUP-y definicję efektywności zatrudnieniowej, środki na utworzenie stanowisk pracy z założenia posiadają stałą wartość - $100 \%$. Może to stanowić zachętę do ich promowania, gdyż w ten sposób wykazuje się dużą efektywność działania organizacji. Najprostszą formą weryfikacji występowania takich zachowań jest sprawdzenie ,popularności” form aktywizacji zawodowej, mierzonej liczbą ich uczestników.

${ }^{12}$ Podstawowe formy aktywizacji zawodowej stosowane przez PUP-y w okresie 2009-2014 to: szkolenia, prace interwencyjne, roboty publiczne, prace społecznie użyteczne, przygotowanie zawodowe w miejscu pracy, podjecie działalności gospodarczej oraz wyposażenie i doposażenie miejsca pracy. 
Tabela 2. Liczba uczestników podstawowych form aktywizacji zawodowej w latach 2009-2014

\begin{tabular}{|l|c|c|c|c|c|c|}
\hline \multicolumn{1}{|c|}{$\begin{array}{c}\text { Forma aktywizacji } \\
\text { zawodowej/lata }\end{array}$} & $\mathbf{2 0 0 9}$ & $\mathbf{2 0 1 0}$ & $\mathbf{2 0 1 1}$ & $\mathbf{2 0 1 2}$ & $\mathbf{2 0 1 3}$ & $\mathbf{2 0 1 4}$ \\
\hline Szkolenia & 168334 & 182363 & 53805 & 80684 & 84919 & 78484 \\
\hline Prace interwencyjne & 40348 & 43151 & 28490 & 31779 & 33932 & 31143 \\
\hline Roboty publiczne & 54019 & 74567 & 22771 & 30384 & 32550 & 32639 \\
\hline $\begin{array}{l}\text { Prace społecznie użytecz- } \\
\text { ne* }\end{array}$ & 65768 & 67631 & 49655 & 46885 & 46479 & - \\
\hline $\begin{array}{l}\text { Przygotowanie zawodowe } \\
\text { w miejscu pracy** }\end{array}$ & 7162 & - & - & - & - & - \\
\hline Staże & 256669 & 299342 & 110516 & 176698 & 194157 & 219710 \\
\hline $\begin{array}{l}\text { Srodki na utworzenie sta- } \\
\text { nowisk pracy, w tym: }\end{array}$ & 92324 & 121620 & 36765 & 61868 & 68736 & 80211 \\
\hline $\begin{array}{l}\text { Podjęcie działalności go- } \\
\text { spodarczej }\end{array}$ & 63964 & 77017 & 26108 & 39410 & 45157 & 49999 \\
\hline $\begin{array}{l}\text { Wyposażenie i doposaże- } \\
\text { nie miejsca pracy }\end{array}$ & 28360 & 44603 & 10657 & 22458 & 23579 & 30212 \\
\hline Razem & 684624 & 788674 & 302002 & 428298 & 460773 & 442187 \\
\hline
\end{tabular}

* Uwzględniane we wskaźniku do 2013 r.

** Uwzględniane we wskaźniku do 2009 r.

Źródło: opracowanie własne na podstawie danych MPiPS, 2010-2015

W analizowanym okresie widać znaczący spadek liczby uczestników między 2010 a 2011 rokiem (por. tab. 2). Był on wynikiem zmniejszenia kwoty środków z Funduszu Pracy na aktywizację osób bezrobotnych z 5,32 mld zł w 2010 roku do 1,92 mld zł w 2011 roku, co automatycznie przełożyło się na ograniczone możliwości obsługi dużej liczby bezrobotnych. Od 2011 roku odnotowuje się jednak systematyczny wzrost środków ${ }^{13}$, któremu towarzyszy wzrost liczby uczestników programów ${ }^{14}$. W 2014 roku najwięcej osób skorzystało ze staży, szkoleń czy łącznie środków na utworzenie stanowisk pracy. Prace interwencyjne i roboty publiczne wybierano najrzadziej.

Chcąc uniknąć wpływu znaczącego spadku środków finansowych, które wydają się stanowić czynnik istotnie oddziałujący na zakres i efektywność działań urzędów, zawęża się okres badawczy do lat 2011-2014. Przyjmuje się zatem, że rok 2011 stanowi punkt odniesienia dla dalszych analiz.

W badanym okresie najwyższe dynamiki wzrostu wśród liczby uczestników odnotowano dla następujących form aktywizacji: wyposażenie i doposażenie miejsca pracy $-183,4 \%$, staże - $98,8 \%$ oraz podjęcie działalności gospodarczej-91,5\% (por. tab. 3). W dwóch przypadkach są to formy, które z założenia

\footnotetext{
${ }^{13}$ Było to 2,46 mld zł dla 2012 r., 3,19 mld zł dla 2013 r. i 3,51 mld zł dla 2014 r.

${ }^{14} \mathrm{~W}$ odniesieniu do 2011 roku.
} 
posiadają stuprocentową efektywność zatrudnieniową. Dla staży odnotowano najwyższą dynamikę wzrostu WEZ (40,9\%), której towarzyszyła jedna z najwyższych dynamik wzrostu uczestników. W przypadku prac interwencyjnych, których efektywność zatrudnieniowa wahała się między 71,4 a 77,5\%, najniższej dynamice wzrostu WEZ (3,8\%) towarzyszyła najniższa dynamika wzrostu liczby uczestników (9,3\%). Dla szkoleń i robót publicznych stosunkowo wysokiej dynamice wzrostu $W E Z$ (odpowiednio 29 i 35,9\%), towarzyszyła relatywnie wysoka dynamika wzrostu liczby uczestników (odpowiednio 45,9 i 43,3\%).

Tabela 3. Wzrost liczby uczestników form aktywizacji zawodowej i WEZ między 2011

$$
\text { a } 2014 \text { rokiem (w \%) }
$$

\begin{tabular}{|l|c|c|}
\hline \multicolumn{1}{|c|}{ Forma aktywizacji zawodowej } & Wzrost liczby uczestników & WEZ \\
\hline Szkolenia & 45,9 & 29,0 \\
\hline Prace interwencyjne & 9,3 & 3,8 \\
\hline Roboty publiczne & 43,3 & 35,9 \\
\hline Prace społecznie użyteczne* & - & - \\
\hline Przygotowanie zawodowe w miejscu pracy** & - & - \\
\hline Staże & 98,8 & 40,9 \\
\hline Środki na utworzenie stanowisk pracy, w tym: & - & - \\
\hline Podjęcie działalności gospodarczej & 91,5 & 0,0 \\
\hline Wyposażenie i doposażenie miejsca pracy & 183,4 & 0,0 \\
\hline
\end{tabular}

* Uwzględniane we wskaźniku do 2013 r.

** Uwzględniane we wskaźniku do 2009 r.

Źródło: opracowanie własne na podstawie danych MPiPS, 2012-2015

Nie bez znaczenia dla „popularności” wyboru danej formy aktywizacji może być jej koszt. Ze względu na ograniczone środki finansowe urzędy mogą ,,preferować" tańsze programy aktywizacyjne. Do takich zachowań zachęca artykuł 109 ustęp 7h-7j ustawy o promocji zatrudnienia i instytucjach rynku pracy, który nakazuje uwzględniać przy przydziale środków finansowych na nagrody również efektywność kosztową ${ }^{15}$. Przepisy zawierają zatem teoretyczną motywację do efektywnego gospodarowania środkami pieniężnymi przez urzędy.

${ }^{15}$ Przez efektywność kosztową (koszt ponownego zatrudnienia) MPiPS rozumie wynik podzielenia kwoty poniesionych w danym roku wydatków (kasowo) na daną formę aktywizacji przez liczbę osób bezrobotnych, które po zakończeniu udziału w danym roku i danej formie aktywizacji uzyskały zatrudnienie w okresie do 3 miesięcy. Natomiast środki finansowe na nagrody są wypłacane, gdy w roku poprzedzającym rok złożenia wniosku osiągnie się wskaźnik efektywności kosztowej podstawowych form aktywizacji zawodowej, o której mowa w artykule 4 ustęp 11 punkt 2 litera c, na poziomie niższym niż 15\% powyżej średniej efektywności kosztowej podstawowych form aktywizacji zawodowej uzyskanej we wszystkich powiatowych urzędach pracy. 
Tabela 4. Efektywność kosztowa form aktywizacji zawodowej w latach 2011-2014 (w zł)

\begin{tabular}{|l|r|r|r|c|}
\hline \multicolumn{1}{|c|}{ Forma aktywizacji zawodowej/lata } & \multicolumn{1}{c|}{$\mathbf{2 0 1 1}$} & \multicolumn{1}{c|}{$\mathbf{2 0 1 2}$} & $\mathbf{2 0 1 3}$ & $\mathbf{2 0 1 4}$ \\
\hline Szkolenia (ze stypendiami) & 5777,51 & 5495,00 & 5219,30 & 4418,42 \\
\hline Prace interwencyjne & 6078,56 & 6626,65 & 7189,68 & 6831,54 \\
\hline Roboty publiczne & 9454,19 & 10260,32 & 11331,16 & 9333,35 \\
\hline Prace społecznie użyteczne & 1587,40 & 2319,36 & 4601,52 & - \\
\hline Staże & 9367,64 & 10365,55 & 9622,62 & 9530,27 \\
\hline Podjęcie działalności gospodarczej & 16081,84 & 17407,71 & 19491,80 & 19667,67 \\
\hline Wyposażenie i doposażenie miejsca pracy & 16159,70 & 17355,56 & 19305,65 & 19696,18 \\
\hline Ogółem & 9020,25 & 10673,66 & 11309,43 & 11174,52 \\
\hline
\end{tabular}

Źródło: opracowanie własne na podstawie danych MPiPS, 2012-2015

Koszt ponownego zatrudnienia ogółem rósł od 2011 do 2013 roku (por. tab. 4), jedynie w 2014 nastąpił jego niewielki spadek (o 1,2\%). W 2014 roku trzema najbardziej kosztownymi formami aktywizacji były: wyposażenie i doposażenie miejsca pracy, podjecie działalności gospodarczej oraz staże. Są to trzy formy aktywizacji, które w latach 2011-2014 odnotowały najwyższą dynamikę wzrostu liczby uczestników. W tym kontekście nie można stwierdzić, że powiatowe urzędy pracy „preferują" tańsze programy aktywizacyjne. Kwoty wydatkowanych środków na wyposażenie i doposażenie miejsca pracy oraz podjecie działalności gospodarczej podlegały systematycznemu wzrostowi w okresie 2011-2014 ${ }^{16}$, co nie wpływało na ograniczenie liczby uczestników tych form aktywizacji. Relatywnie tanie prace interwencyjne przyciągały w tym okresie najmniej uczestników (por. tab. 2).

Zgodnie z definicją paradoks efektywności odnosi się do słabej korelacji między wskaźnikiem efektywności a wynikającym z niego efektem działań. Chcąc zweryfikować powyższą tezę, zbadano korelację wskaźnika efektywności zatrudnieniowej w okresie 2009-2014 (dla 16 województw) z następującymi wielkościami: stopą odpływów z bezrobocia z tytułu podjęcia pracy i stopą odpływów z bezrobocia $\mathrm{z}$ tytułu zatrudnienia po aktywizacji.

Chcąc uwzględnić różnice między województwami, np. w wielkości województwa czy liczbie bezrobotnych, zmodyfikowano współczynnik korelacji liniowej Pearsona, używając zamiast jednej średniej dla wszystkich obserwacji, 16 średnich (inna średnia dla każdego województwa). Do obliczeń używa się zatem dwóch wersji współczynnika. W przypadku odpływów z bezrobocia z tytułu zatrudnienia po aktywizacji liczbę osób zaktywizowanych koryguje się o wielkość

${ }^{16}$ Dynamika wzrostu efektywności kosztowej w badanym okresie wyniosła dla: wyposażenia i doposażenia miejsca pracy $21,9 \%$, a dla podjęcia działalności gospodarczej $22,3 \% \%$. W przypadku prac interwencyjnych było to natomiast $12,4 \%$. 
indeksów: wydatków z Funduszu Pracy i efektywności kosztowej ${ }^{17}$. W obu przypadkach jako wielkości stałe przyjmuje się wartości z 2011 roku.

Tabela 5. Zależność między WEZ a stopą odpływów z bezrobocia z tytułu podjęcia pracy i stopą odpływów z bezrobocia z tytułu zatrudnienia po aktywizacji

\begin{tabular}{|l|c|c|}
\hline \multicolumn{1}{|c|}{ Zmienna } & $\begin{array}{c}\text { Wspólczynnik korelacji } \\
\text { liniowej Pearsona }\end{array}$ & $\begin{array}{c}\text { Poziom } \\
\text { istotności }\end{array}$ \\
\hline Stopa odpływów z bezrobocia - podjecie pracy & 0,36 & $p<0,001$ \\
\hline $\begin{array}{l}\text { Stopa odpływów z bezrobocia - podjecie pracy } \\
\text { (16 średnich) }\end{array}$ & 0,50 & $p<0,001$ \\
\hline $\begin{array}{l}\text { Stopa odpływów z bezrobocia z tytułu } \\
\text { zatrudnienia po aktywizacji* }\end{array}$ & 0,16 & $p=0,128$ \\
\hline $\begin{array}{l}\text { Stopa odpływów z bezrobocia z tytułu } \\
\text { zatrudnienia po aktywizacji* (16 średnich) }\end{array}$ & 0,07 & $p=0,487$ \\
\hline
\end{tabular}

* Wydatki i koszty stałe z 2011 roku.

Źródło: obliczenia własne na podstawie danych MPiPS i GUS

Dla 96 obserwacji otrzymano współczynniki korelacji liniowej Pearsona przedstawione $\mathrm{w}$ tabeli 5 . Na ich podstawie stwierdza się, że występuje słaba $(0,36)$ lub umiarkowana $(0,50)$ dodatnia korelacja $(16$ województw) (poziom istotności poniżej $0,1 \%, p<0,001)$ między $W E Z$ a stopą odpływu z bezrobocia z tytułu podjęcia pracy ${ }^{18}$. Stopa odpływów jest jednak w tym przypadku w niewielkim stopniu (od około 20 do $30 \%$ ) pochodną podejmowanych działań aktywizacyjnych. Większość podjęć pracy generowana jest przez rynek. Z tego względu otrzymane wyniki mogą być wielkościami pozornymi.

Dokładniejszą miarę stanowi stopa odpływu z bezrobocia z tytułu zatrudnienia po aktywizacji. $\mathrm{W}$ tym przypadku otrzymane wartości $(0,16, p=0,128$ i $0,07, p=0,487)$ wskazują na brak istotnej zależności między $W E Z$ a stopą odpływu z bezrobocia z tytułu zatrudnienia po aktywizacji. Otrzymane wyniki mogą wskazywać na występowanie paradoksu efektywności, zwłaszcza że wniosek ten koresponduje z wcześniejszą analizą danych.

${ }^{17}$ Korekcja ta jest niezbędna, aby uzyskać realny wzrost (spadek) między okresami. Przykładowo, w roku 2010 wydatki z Funduszu Pracy wynosiły 5,32 mld zł, a w roku 2011 tylko 1,92 mld zł. Miało to niebagatelny wpływ na nominalną liczbę osób zaktywizowanych w tych okresach, a przez to na stopę ich odpływów. Z tego względu należało przeliczyć liczbę osób zaktywizowanych, przyjmując stałą kwotę wydatków dla każdego okresu od 2009 do 2014 roku i uzyskując ich realną wielkość. Identycznie postąpiono w przypadku efektywności kosztowej.

${ }^{18}$ Przy ocenie siły zależności między zmiennymi przyjęto przedziały: $\left.<0 ; 0,2\right)$ brak korelacji; $<0,2 ; 0,4)$ korelacja słaba; $<0,4 ; 0,6)$ korelacja umiarkowana; $<0,6 ; 0,8)$ korelacja wysoka; $<0,8 ; 0,9$ ) korelacja bardzo wysoka; $<0,9 ; 1>$ zależność pełna. 


\section{Podsumowanie}

Na podstawie prowadzonych teoretycznych rozważań odnoszących się do paradoksu efektywności oraz w kontekście przeprowadzonej analizy danych wydaje się, że wskaźnik efektywności zatrudnieniowej może tracić swoją zdolność do mierzenia efektywnych działań przez PUP-y. Ze względu na jego konstrukcję, tj. uwzględnienie form aktywności o z góry założonej stuprocentowej efektywności, występuje zjawisko spijania śmietanki (ang. cream skimming, cherry picking) ${ }^{19}$. Z analizy danych wynika, że formy aktywizacji posiadające z góry określoną stuprocentową efektywność miały w okresie 2011-2014 najwyższe dynamiki wzrostu liczby uczestników. Jednocześnie były to formy o najwyższych kosztach (niska efektywność kosztowa). W przypadku pozostałych form aktywizacji stwierdzono, że stosunkowo wysokiej (niskiej) dynamice wzrostu $W E Z$ towarzyszyła relatywnie wysoka (niska) dynamika wzrostu liczby uczestników (relatywnie wysoka - staże, szkolenia i roboty publiczne; relatywnie niska - prace interwencyjne). Wydaje się, że urzędy w sposób ,naturalny” skupiają się na tym, co pozwoli wykazać ich efektywność we wskaźnikach oraz otrzymać odpowiednie środki na nagrody. W tym kontekście można stwierdzić, że PUP-y podlegają procesom pozytywnego i odwrotnego uczenia się, co znajduje odzwierciedlenie w ciągłym wzroście od 2009 roku wartości wskaźnika efektywności zatrudnieniowej oraz liczbie urzędów, które w 2014 roku poprawiły jego wartość $(85,9 \%)$. Do takich zachowań motywują przepisy ustawy o promocji zatrudnienia. Wydaje się, że w wyniku występowania powyższych procesów zdolność do mierzenia efektywności przez wskaźnik efektywności zatrudnieniowej ulega systematycznemu zmniejszeniu.

Na uleganie paradoksowi efektywności przez WEZ wydaje się też wskazywać brak korelacji między nim a stopą odpływu z bezrobocia z tytułu zatrudnienia po aktywizacji. Natomiast występująca słaba lub umiarkowana korelacja między WEZ a stopą odpływu z bezrobocia $\mathrm{z}$ tytułu podjęcia pracy może być tylko pozorna.

Wskazane w prowadzonej analizie słabości wskaźnika efektywności zatrudnieniowej nie oznaczają, że należy zrezygnować z jego stosowania. Należy jednak dokonać jego modyfikacji. Przede wszystkim wydaje się, że wskaźnik nie spełnia kryterium słuszności i wiarygodności, jakim powinien charakteryzować się dobry miernik. Przyjmowany w definicji MPiPS okres do trzech miesięcy jest nieadekwatny do celu, jakim jest długotrwałe wyjście z zasobu bezrobocia. Temu powinna przede wszystkim służyć aktywizacja, a jej skuteczność należy weryfikować w dłuższym okresie. Na ten problem zwracała uwagę również NIK. W raporcie z 2015 roku obliczono niektóre wskaźniki efektywności zatrudnieniowej dla roku po okresie aktywizacji. Przykładowo: w badanych latach

${ }^{19} \mathrm{Na}$ występowanie tego zjawiska zwracała już uwagę E. Kryńska (2009: 29). Zostało też ono zauważone w ogólnopolskim badaniu w latach 2002-2006 przez E. Strojną (2007). 
2011-2013 skuteczność staży wyliczona przez NIK wynosiła od 33,1\% do 39,4\%, szkoleń od $18,6 \%$ do $21 \%$. Wartości te były zatem znacznie niższe niż prezentowane przez MPiPS (NIK, 2015: 8-9). Przedstawiony w raportach MPiPS obraz działalności powiatowych urzędów pracy był zatem znacznie bardziej optymistyczny od rzeczywistego. Jest to zjawisko charakterystyczne dla występowania paradoksu efektywności.

\section{Bibliografia}

Bruijn H. de (2007), Managing Performance in the Public Sector, 2nd ed., Routledge, London.

Christensen T., Laegreid P. (2015), Performance and Accountability - A Theoretical Discussion and an Empirical Assessment, „Public Organization Review”, vol. 15, s. 207-225.

Dooren W. van, Bouckaert G., Halligan J. (2015), Performance Management in the Public Sector, 2nd ed., Routledge, London.

Grizzle G.A. (2002), Performance Measurement and Dysfunction, „Public Performance \& Management Review", vol. 25, no. 4, s. 363-369.

Kryńska E. (2009), Powiatowa perspektywa polityki rynku pracy, „Polityka Społeczna”, nr 11-12, s. 29-31, http://www.ipiss.com.pl/wp-content/uploads/downloads/2012/10/ps_11-12_2009_e_ krynska.pdf [dostęp: 9.06.2016].

Leeuw F.L. (2008), Ewaluacja w Europie. Wyzwania przyszłości, „Państwo i Rynek”, nr 1, s. 1-7.

Meyer M.W., Gupta V. (1994), The performance paradox, „Research in Organizational Behavior”, vol. 16, s. 309-369.

Meyer M.W., O'Shaughnessy K. (1993) Organizational design and the performance paradox, [w:] R. Swedberg (ed.), Explorations in economic sociology, Russell Sage Foundation, New York.

MPiPS (2010), Efektywność podstawowych form aktywizacji zawodowej realizowanych w ramach programów na rzecz promocji zatrudnienia, tagodzenia skutków bezrobocia i aktywizacji zawodowej w 2009 roku, Warszawa.

MPiPS (2011), Efektywność podstawowych form aktywizacji zawodowej realizowanych w ramach programów na rzecz promocji zatrudnienia, tagodzenia skutków bezrobocia i aktywizacji zawodowej w 2010 roku, Warszawa.

MPiPS (2012), Efektywność podstawowych form aktywizacji zawodowej realizowanych w ramach programów na rzecz promocji zatrudnienia, tagodzenia skutków bezrobocia i aktywizacji zawodowej w 2011 roku, Warszawa.

MPiPS (2013), Efektywność podstawowych form aktywizacji zawodowej realizowanych w ramach programów na rzecz promocji zatrudnienia, tagodzenia skutków bezrobocia i aktywizacji zawodowej w 2012 roku, Warszawa.

MPiPS (2014), Efektywność podstawowych form aktywizacji zawodowej realizowanych w ramach programów na rzecz promocji zatrudnienia, łagodzenia skutków bezrobocia i aktywizacji zawodowej w 2013 roku, Warszawa.

MPiPS (2015), Efektywność podstawowych form aktywizacji zawodowej realizowanych w ramach programów na rzecz promocji zatrudnienia, łagodzenia skutków bezrobocia i aktywizacji zawodowej w 2014 roku, Warszawa.

NIK (2015), Skuteczność wybranych form aktywnego przeciwdziałania bezrobociu w niektórych województwach, Rzeszów, https://www.nik.gov.pl/plik/id,8905,vp,11060.pdf [dostęp: 14.06.2016].

Osoborne S.P. (2006), The New Public Governance?, ,Public Management Review”, vol. 8, s. 377-387. 
Piwowarski R. (2011), Znaczenie przejrzystości w polityce fiskalnej, Wydawnictwo Uniwersytetu Łódzkiego, Łódź.

Rosen D.E. (1993), Improving Public Sector Productivity. Concepts and Practice, Sage Publications, London.

Smith P. (1990), The Use of Performance Indicators in the Public Sector, „, Journal of the Royal Statistical Society", vol. 153, no. 1, s. 53-72.

Smith P. (1995), On the unintended consequences of publishing performance data in the public sector, „International Journal of Public Administration”, vol. 18, s. 277-310.

Strojna E. (2007), Ustugi szkoleniowe i instrumenty podnoszenia kwalifikacji. Dane statystyczne 2002-2006, MPiPS, Warszawa.

Ustawa z dnia 20 kwietnia 2005 r. o promocji zatrudnienia i instytucjach rynku pracy (Dz.U z 2004 r. Nr 99, poz. 1001).

Utz H. (2011), The Impact of Performance Budgeting on Public Management, Ph. D. Dissertation no. 3826, The University of St. Gallen, s. 1-112, http://wwwl.unisg.ch/www/edis.nsf/SysLkpByIdentifier/3826/\$FILE/dis3826.pdf [dostęp: 8.06.2016].

Thiel S. van, Leeuw F.L. (2002), The Performance Paradox in the Public Sector, „Public Performance \& Management Review", vol. 25, no. 3, s. 267-281.

\section{Does Employment Effeciveness Indicator Yield a Performance Paradox?}

Abstract: In the report about effectiveness of selected Active Labor Market Programs (ALMP) published in 2015 by the Supreme Audit Office (NIK) one can find conclusions which may indicate the occurrence possibility of the performance paradox. This applies primarily to the employment effectiveness indicator (WEZ), which is widely used by the district labor offices in Poland. The aim of the article is to characterize the phenomenon of the performance paradox and assess the possibility of its occurrence in the case of WEZ. To complete the goal data published by the Ministry of Labour and the Central Statistical Office relating to ALMP for the years 2009-2014 is analyzed. Moreover, correlation analysis between WEZ and the rates of outflow from unemployment due to employment and employment after participation in ALMP is conducted. The analysis show that the presented by Ministry of Labour reports about effectiveness of district labor offices are more optimistic than the actual. This is a phenomenon characteristic for the performance paradox, which WEZ seems to yield.

Keywords: performance paradox, Active Labor Market Programs (ALMP), public sector effectiveness JEL: H4, J08

\begin{tabular}{|l|l|}
\hline \multirow{2}{*}{ OPEN ACCESS } & $\begin{array}{l}\text { C by the author, licensee Łódź University - Łódź University Press, Łódź, Poland. } \\
\text { This article is an open access article distributed under the terms and conditions } \\
\text { of the Creative Commons Attribution license CC-BY } \\
\text { (http://creativecommons.org/licenses/by/3.0/) }\end{array}$ \\
\cline { 2 - 2 } \\
Received: 2016-08-14; verified: 2016-11-14. Accepted: 2016-12-15
\end{tabular}

